\title{
Science and Technology ODA Promotion of Korea through ICT of Global Problem Solving Centers -Suggestion on the mid- and short-term projects promotion of science and technology ODA roadmap-
}

\author{
Woo-Kyun Jung ${ }^{1}$, Kwanwoo Shin², Seongpil Jeong ${ }^{3}$, Hunkyun Park ${ }^{4}$, Eun Sun Park ${ }^{5}$, Sung-Hoon Ahn ${ }^{6, \dagger}$ \\ ${ }^{1}$ Soft Robotics Research Center, Seoul National University, 1 Gwanak-ro, Gwanak-gu, Seoul 08826, Republic of Korea \\ ${ }^{2}$ Department of Chemistry, Sogang University, 35 Baekbeom-ro, Mapo-gu, Seoul 04107, Republic of Korea \\ ${ }^{3}$ Water Cycle Research Center, Korea Institute of Science and Technology, 14 gil 5 Hwarang-ro, Seongbuk-gu, \\ Seoul 02792, Republic of Korea \\ ${ }^{4}$ Solarinno Co., Ltd. Electronics and Telecommunications Research Institute, Gajeong-ro 218, Yuseong-gu 34129, \\ Daejeon, Republic of Korea \\ ${ }_{5}^{5}$ Academic Society for Appropriate Technology, 79 Seoun-ro, Seocho-gu, Seoul 06726, Republic of Korea \\ ${ }^{6}$ Department of Mechanical Engineering, Seoul National University, 1 Gwanak-ro, Gwanak-gu, Seoul 08826, Republic of Korea
}

\section{글로벌문제해결거점 ICT화를 통한 한국형 과학기술 ODA 추진 -과학기술 ODA 중 · 단기 과제 추진에 대한 제언-}

정우균 ${ }^{1}$, 신관우 ${ }^{2}$, 정성필 ${ }^{3}$, 박헌균 $^{4}$, 박은선 $^{5}$, 안성훈 $^{6, \uparrow}$

${ }^{1}$ 서울대학교 인간중심소프트로봇기술연구센터, 서울시 관악구 관악로 1

${ }^{2}$ 서강대학교 화학과, 서울시 마포구 백범로 35

3 한국과학기술연구원 물자원순환연구센터, 서울시 성북구 화랑로 14 길 5

${ }^{4}($ 주)솔라리노, 대전시 유성구 가정로 218 한국전자통신연구원 융합기술생산센터

${ }^{5}$ 적정기술학회, 서울시 서초구 서운로 79

${ }^{6}$ 서울대학교 기계공학부, 서울시 관악구 관악로 1

\begin{abstract}
$\mathrm{UN}$ 의 SDGs 추진을 위해 우리나라는 2019년 K-SDGs를 제시하였으나, SDGs의 중요한 이행 수단인 과학기술 분야에 대한 역할과 과제가 구체화 되지 않았다. 이에, 2020년 과기정통부의 정책연구과제인 '신남방정책 확산 및 $2030 \mathrm{SDGs}$ 실현을 위한 과학기술 $\mathrm{ODA}$ 추진 로드맵’을 통해 SDGs 추진을 위한 과학기술 $\mathrm{ODA}$ 의 역할을 정립하고, 물, 기후변화, 에너지, ICT 등 10 개 분야에 대한 향후 10 년간의 추진 목표와 전략 및 중점과제를 도출하였다. 본 논문에서는 SDGs 실현을 위한 과학기술 ODA 추진 로드맵의 30 개 중점과제를 분석하여 효과적인 로드맵 추진을 위한 중·단기 과제 및 추진방안을 제안하고자 한다. 각 분야의 중점과제 중 로드맵 추진 여건 조성 및 통합이 가능한 ICT/스마트화, 글로벌 문제해결거점, 협력/소통 플랫폼, 비즈니스 모델/창업지원플랫폼/리빙랩의 4개 공통 키워드를 도출하고, 이를 로드맵의 세부 내용과 연계하여 과학기술 ODA 네트워크 구축, 리빙랩 연계 창업지원 비즈니스 플랫폼 구축, 수원국 현지 스마 트화, 글로벌문제해결거점 확장 및 지속성 확보의 4 개 중·단기 과제로 설정하였다. 도출된 중·단기 과제에 대해서는 글 로벌문제해결거점의 ICT화를 통한 추진 방안을 제시하였다. 본 논문에서 제시하는 중·단기 과제의 추진은 과학기술 $\mathrm{ODA}$ 로드맵의 보다 효과적인 달성에 기여할 수 있을 것이며, 이를 통해 우리나라의 SDGs 이행 또한 높은 성과를 올 릴 수 있을 것으로 기대한다.
\end{abstract}

${ }^{\dagger}$ To whom correspondence should be addressed.

E-mail: ahnsh@snu.ac.kr

Received: 23 September 2021, Revised: 27 October 2021,

Accepted: 27 October 2021
The Korean government proposed the K-SDGs in 2019 to promote the UN SDGs, but the role and tasks of science and technology, an important means of implementing the SDGs, have not been materialized. 
Accordingly, the role of science and technology ODA for the SDGs was established through the Ministry of Science and ICT's policy research project 'Science and Technology ODA Promotion Roadmap for Spreading the New Southern Policy and Realizing the 2030 SDGs'. In addition, goals, strategies, and core tasks for the next 10 years were derived in 10 fields such as water, climate change, energy, and ICT. In this paper, we analyze 30 key tasks of the ODA promotion roadmap for science and technology for the realization of SDGs, and propose mid- and short-term tasks and implementation plans for effective roadmap promotion. Among the key tasks in each field, four common elements were derived: ICT/smartization, a global problem-solving center, cooperation/communication platform, and business model/startup support platform/living lab that can create and integrate roadmap implementation conditions. In addition, the four mid- and short-term tasks, 1) Establishment of science and technology ODA network, 2) Establishment of living lab business platform linked to start-up support business, 3) Local smartization of recipient countries, and 4) Expand and secure sustainability of global problem-solving centers, were set in relation to the implementation of the detailed roadmap. For the derived mid- and short-term tasks, detailed implementation plans based on the ICTization of global problem-solving centers were presented. The implementation of the mid- and short-term tasks presented in this paper can contribute to the more effective achievement of the science and technology ODA roadmap, and it is expected that Korea's implementation of SDGs will also achieve high performance.

KEYWORDS: Sustainable development goals, Science and technology ODA roadmap, Global problem solving center, Information \& communications technology (ICT)

서론

2015년 9월, UN 특별정상회의는 회원국 만장일치로 SDGs 17 개 목표를 채택하였다(UN SDGs Goals). SDGs는 2000년부터 개발도상국 사회문제 해결에 중점을 두고 추진 되었던 MDGs (Millennium Development Goals)에 이어 2030년까지 달성하고자 하는 개발도상국과 선진국 모두에 적용되는 인류의 공동 목표를 명시하였다. Figure 1은 SDGs 17 개 목표로서, 본 목표는 사회발전, 경제성장, 환경보존의 각 분야에서 인간의 존엄성을 회복하고 적절한 수준의 생 계를 유지할 수 있는 경제환경을 구축하며, 기후변화와 자 연재해에 대응하고 환경을 보호함으로써 궁극적으로는 인 류의 지속가능성을 보장하고자 설정되었다. 과학기술은 이
를 구현하기 위한 중요한 이행수단으로, 물, 에너지, 환경, 기후, 정보통신기술, 농업, 감염병 등 거의 모든 분야에 연 계되어 있다(이향희 \& 이명진, 2020). 대한민국은 2019년에 $\mathrm{UN} \mathrm{SDGs}$ 를 기반으로 '국가 지속가능발전목표 수립 보고서 2019 (K-SDGs)'를 통해 SDGs 추진 계획을 제시하였으나, 과학기술 분야의 역할과 과제는 구체적으로 반영되어 있지 않은 상태이다(Korea SDGs).

한편, 2019년 이후 전 세계를 위기로 몰아가고 있는 코로 나19는 SDGs의 추진에 있어 큰 장애물로 대두되고 있다. UN은 '2020년 SDG 이행 보고서'를 통해 코로나19의 영향 으로 개발도상국의 경제적, 사회적 취약성 심화를 우려하며 ODA(Official Development Assistance, 공적개발원조)의 역 할 확대를 강조하였는데, 우리나라도 이에 부응하여 ODA

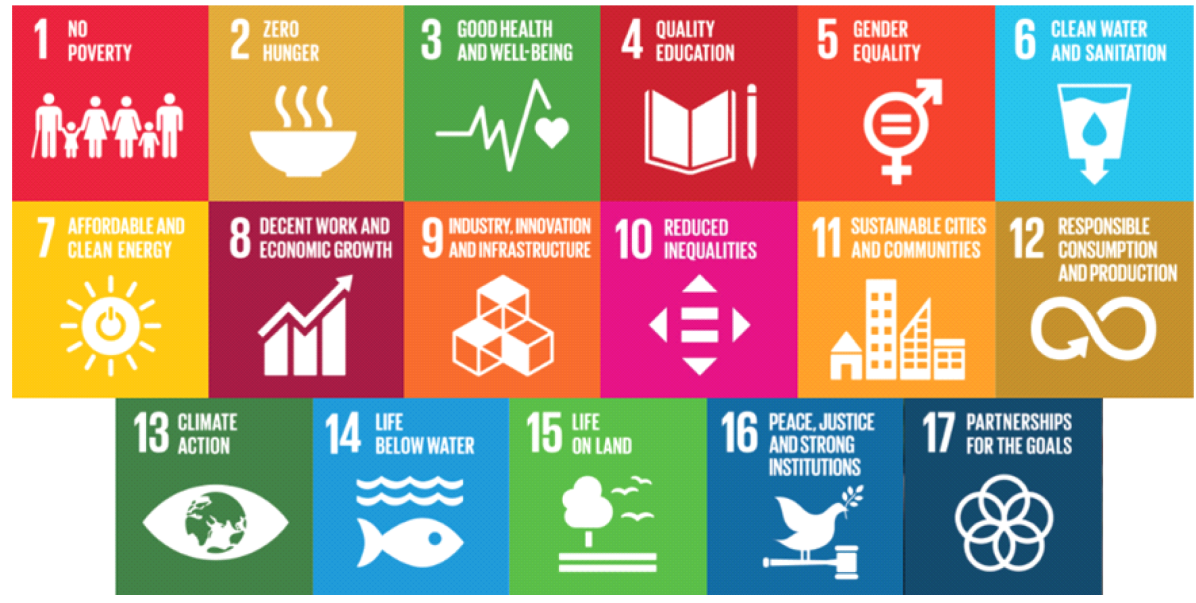

Figure 1. UN의 17 개 SDGs[1] 
예산을 증액하는 등의 노력을 기울이고 있다(정지선 \& 유 애라, 2020). 또한, 우리나라는 세계에서 처음으로 ODA 수 원국에서 공여국으로 전환한 국가로서, 한국의 $\mathrm{ODA}$ 는 국 제사회에 좋은 귀감이 되고 있다(강희종 \& 임덕순, 2014). 한국의 ODA는 적정기술과 밀접한 관계를 가지며 추진되 어 왔다. 과학기술 ODA 추진의 성과에 있어서 적정기술의 역할과 중요성이 강조되었고(강인수 등, 2016), 한국형 적정 기술의 방향 중 하나로 '국제사회에 책임있는 한국형 ODA 프로그램 개발’이 제시되기도 하였는데(안성훈 등, 2017), 이를 수원국 현장에서 실현하고 있는 팀들이 적정과학기술 을 기반으로 한 '글로벌문제해결거점'이다. 아시아, 아프리 카 등에 위치한 글로벌문제해결거점은 현지의 상황을 고려 한 적정과학기술을 이용하여 SDGs를 실현하기 위한 과학 기술 $\mathrm{ODA}$ 사업을 적극 추진하고 있다.

신관우 등(2020)은 우리나라의 SDGs 추진에 있어 과학기 술 ODA의 역할을 구체화하고 향후 10 년간 분야별 추진 방 향을 정립하고자 '신남방정책 확산 및 2030 SDGs 실현을 위한 과학기술 ODA추진 로드맵’을 제안하였다. 물, 기후변 화, 에너지 등의 10 개 분야에 대하여 2030년까지의 추진 목 표를 설정하고 핵심 전략과제와 중점과제를 도출함으로써 $\mathrm{SDGs}$ 실현을 위한 과학기술 $\mathrm{ODA}$ 의 청사진을 제시하였다. 하지만, 코로나19와 같은 글로벌 위기에 대한 대응과 로드 맵 추진을 위한 방법적 차원의 중·단기 과제에 대한 추가적 인 고려가 필요한 상황이다.

이에, 본 논문에서는 $2030 \mathrm{SDGs}$ 실현을 위한 과학기술 $\mathrm{ODA}$ 로드맵의 실질적 추진을 위해 분야별 중점과제를 통 합적으로 분석하여 중·단기 과제를 도출하고 글로벌문제해 결거점을 기반으로 한 추진 방안을 제시하고자 한다. 아프 리카 및 동남아시아 8 개국에 설치된 글로벌문제해결거점을 과학기술 $\mathrm{ODA}$ 추진의 구심점으로 활용함으로써 보다 성과 있는 로드맵 추진이 가능할 것이다.

\section{SDGs 실현을 위한 과학기술 ODA 추진 로 드맵}

\section{1. 로드맵 도출 배경과 추진 경과}

$\mathrm{UN}$ 의 SDGs 채택에 따라 우리나라는 2030년 까지 이행 하여야 할 의무에 대응하고자 2019년 17개 목표에 대한 122 개 세부목표와 214개 지표를 포함하는 K-SDGs를 설정하였 다(Korea SDGs). 하지만, 앞서 언급한 바와 같이 K-SDGs에 는 과학기술 분야의 역할이 반영되어 있지 않은 상태로, 교 육, 물, 에너지, 기후변화, 국제협력 등에 중요한 부분인 과 학기술 ODA에 대한 추진계획이 구체화되어 있지 않다.

한편, 지금까지의 과학기술 ODA 사업의 발굴 및 추진 방
향은 SDGs의 목표 및 방향에 부합되기는 하였으나, 과학기 술 ODA에 대한 비전과 2030년 SDGs의 목표를 달성하기 위 한 중·장기적 관점에서 큰 틀을 제시하지 못한 상태에서 단 편적으로 추진되고 있다는 문제점이 제기되기도 하였다. 이 에, SDGs의 2030년 목표에 부합되는 과학기술 ODA의 역 할을 정립하고, 향후 10 년간 추진하여야 할 방향을 제시하 고자 SDGs 구현을 위한 과학기술 $\mathrm{ODA}$ 추진 로드맵이 제 안되었다(신관우 등, 2020).

도출된 과학기술 ODA 추진 로드맵은 물, 기후변화, 에너 지 등 10 개 분야의 전문가 40 명으로 자문위원회를 구성하 고, 세미나를 통하여 국내·외 현황분석, 분야별 키워드 및 중 점 과제 도출, 전략 및 비전 제안 등의 과정을 거쳐 수립되 었다. 총 3 차로 진행된 전문가 세미나를 통하여 SDGs에 부 합되는 향후 10 년간 추진하여야 할 과학기술 ODA의 목표 및 키워드가 제시되었으며, 이를 기반으로 전략 및 중점 과 제가 설정되었다.

\section{2. 로드맵의 분야별 목표 및 추진 과제}

본 절에서는 'SDGs 실현을 위한 과학기술 ODA 추진 로 드맵'의 주요 내용을 요약하였다. SDGs 실현을 위한 과학 기술 $\mathrm{ODA}$ 추진 로드맵은 '통합적 과학기술 ODA 융합 연 계 지원 체계 구축을 통한 적정과학기술지원 글로벌화 확 산'을 핵심 전략으로 설정하였는데, 이는 수원국의 상황을 고려한 적정과학기술의 지원을 통해 수원국 현지의 생존 및 생계 문제를 근본적으로 해결할 뿐만 아니라 삶의 질을 제 고하여 빈곤의 극복과 경제 성장을 수원국 스스로가 추진 할 수 있는 역량을 갖추도록 하자는 것이다.

이를 추진하기 위한 방안으로, 연구기반의 조성과 산업발 전의 지원, 지속가능개발 문제해결 활성화를 제시하였는데, 연구기반의 조성은 과학기술분야의 핵심 연구인력을 양성 하고 연구개발 인프라 구축 및 지원을 통해 적정기술 국내 연구집단을 육성하는 한편, 글로벌 현지 테스트 베드를 통 해 확산하는 방안이다. 산업발전의 지원은 수원국 현지의 혁 신클러스터 구축을 위한 지역 산학연 연계체계를 강화하고 기술사업화를 지원하여 신산업 및 사회혁신을 위한 스타트 업에 대한 지원체계를 구축하는 것이며, 지속가능개발 문제 해결 활성화는 리빙랩과 같은 현지 문제의 해결책을 스스 로 고민하고 해결하는 새로운 플랫폼의 개발을 통해 과학 기술 혁신을 기반으로 다양한 기술혁신 주체의 참여를 유 도하여 혁신적 해결방식을 도출하고자 하는 것이다.

기본 핵심 전략을 기반으로 물, 기후변화, 에너지, 글로벌 문제해결거점, ICT, 국제협력, 사회혁신 지속가능, 교육, 보 건의료, 환경의 10 개 분야에 대한 세부 목표와 핵심 전략 및 중점과제를 도출하였다. Table 1은 각 분야별 관련 SDGs, 목 
Table 1. SDGs 실현을 위한 과학기술 ODA 로드맵 : 목표, 핵심 전략 및 중점 과제

\begin{tabular}{|c|c|c|c|}
\hline 분야 & 관련 SDGs & 목표 & 핵심 전략 / 중점 과제 \\
\hline 물 & G6, G13 & $\begin{array}{l}\text { 현장 결합형 지속 가능한 물/위 } \\
\text { 생 적정기술의 개발/확산/사업 } \\
\text { 화 }\end{array}$ & $\begin{array}{l}\text { 핵심 전략 : 국제협력을 통한 지속 가능한 물/위생 사업추진 } \\
\text { 1. 현지에서 생산/관리 가능한 초저가 개인용 독립형 해수 담수기 개발 } \\
\text { 2. 현지 간헐 운전되는 물생산 시스템의 운전 안정성 확보 기술 } \\
\text { 3. 글로벌문제해결 현지거점센터 구축과 국제기구와의 공동협력 사업 추진 } \\
\end{array}$ \\
\hline 기후변화 & G5, G6, G13 & $\begin{array}{l}\text { 기후변화 대응을 위한 지속가 } \\
\text { 능한 물 관리 모델 구축/확산 }\end{array}$ & $\begin{array}{l}\text { 핵심 전략 : 지속가능한 기후변화 대응력 확보 } \\
\text { 1. 염분 침입 저지를 위한 빗물폰드/Bio Pond+MAR 기술 개발 } \\
\text { 2. 섬/연안 지역 통합 물관리 모델 개발 } \\
\text { 3. 지속가능한 물관리를 위한 비즈니스 모델 개발 } \\
\end{array}$ \\
\hline 에너지 & G1, G7, G9 & 지속가능한 신재생에너지 확보 & $\begin{array}{l}\text { 핵심 전략 : 지속가능 에너지 보급/지역성장 } \\
\text { 1. K-ODA에너지 리빙랩 테스트베드 구축 및 확장성 기반의 에너지 유닛 개발 } \\
\text { 2. 독립형 마이크로그리드 스마트 통합전력관리 기술 개발 } \\
\text { 3. 지속가능성 확보를 위한 비즈니스형 에너지 기술 개발 }\end{array}$ \\
\hline $\begin{array}{l}\text { 글로벌 } \\
\text { 문제해결 } \\
\text { 거점 }\end{array}$ & G9, G11, G13 & $\begin{array}{l}\text { 지속가능 기술구현을 통한 글 } \\
\text { 로벌 거점지역 문제해결 및 국 } \\
\text { 제협력 }\end{array}$ & $\begin{array}{l}\text { 핵심 전략 : 개도국 포용적 시장 확대 및 지속 가능 개발 } \\
\text { 1. 기존 거점센터 2단계 전략 기술의 ICT 패키징 및 스마트시스템 구축 } \\
\text { 2. 글로벌 리빙랩 중점기술에 대한 스마트 연계체계 개발 } \\
\text { 3. 거점센터의 기술성과 운영지원을 위한 글로벌 통합기술(R\&DB) 비즈니스 지원 플 } \\
\text { 랫폼 추진 }\end{array}$ \\
\hline ICT & $\begin{array}{c}\text { G4, G8, G9, } \\
\text { G10, G11, G17 }\end{array}$ & $\begin{array}{l}\text { 수원국 농촌형 오픈소스 기반 } \\
\text { ICT 교육, 스타트업을 통한 마 } \\
\text { 을혁신 기반 형성 }\end{array}$ & $\begin{array}{l}\text { 핵심 전략 : ICT Villiage, ICT Education, ICT Start-up } \\
\text { 1. 마을 ICT 센터 } \\
\text { 2. OS(Open source) } 24 \\
\text { 3. 글로벌 스타트업 경진대회 }\end{array}$ \\
\hline 국제협력 & G17 & $\begin{array}{l}\text { 과학기술 ODA를 위한 글로벌 } \\
\text { 다자협력 기반 구축 주도 }\end{array}$ & $\begin{array}{l}\text { 핵심 전략 : 주도적 글로벌 다자협력 디지털 플랫폼 활용 및 국제사회에서 포용적 } \\
\text { 과학기술문화 교육선도 } \\
\text { 1. 과학기술 ODA 국제협력을 위한 다자협력 플랫폼 및 인력양성 기반 설계 }\end{array}$ \\
\hline $\begin{array}{l}\text { 사회혁신 } \\
\text { 지속가능 }\end{array}$ & G9, G11 & $\begin{array}{l}\text { 개도국 모든 사회구성원의 수 } \\
\text { 평적 참여와 실천을 통한 사회 } \\
\text { 적 가치 실현 }\end{array}$ & $\begin{array}{l}\text { 핵심 전략 : 지속가능한 사회혁신 구현 } \\
\text { 1. 개도국 지역거점 소통협력공간 조성 } \\
\text { 2. 개도국 사회혁신 선도사업 추진 } \\
\text { 3. 개도국 사회혁신 기반 구축 }\end{array}$ \\
\hline 교육 & G4 & $\begin{array}{l}\text { 제 } 3 \text { 세계 개발도상국 산업화 지 } \\
\text { 원 연계형 ICT-과학/공학 기술 } \\
\text { 교육 및 국가 고등 인력 육성 }\end{array}$ & $\begin{array}{l}\text { 핵심 전략 : 기술교육연계 산업 육성 / 온라인 교육 시스템 구축 } \\
\text { 1. 시니어 과학기술자를 활용한 ASEAN-AFRICA K-공학교육 지원 사업 } \\
\text { 2. 포스트 코로나 시대 비대면 온라인 ICT-과학기술 교육 지원 } \\
\text { 3. 청년 적정기술 개발도상국 창업 교육 지원 사업 } \\
\text { 4. 제3세계 현지 문제 해결형 적정기술 리빙랩 사업 }\end{array}$ \\
\hline 보건의료 & $\begin{array}{c}\mathrm{G} 1, \mathrm{G} 2, \mathrm{G} 3, \mathrm{G} 6 \\
\mathrm{G} 8\end{array}$ & $\begin{array}{l}\text { 현장결합형 적정 질병관리 기 } \\
\text { 술 개발 }\end{array}$ & $\begin{array}{l}\text { 핵심 전략 : 디지털 기술기반 저비용 고효율 적정 질병관리 기술 구축 } \\
\text { 1. 신종 감염병 대응체계 구축 } \\
\text { 2. 비감염성 만성질환 적정 관리 기술 개발 } \\
\text { 3. 포스트 코로나 의료의 체계적 접근 역량 개발 } \\
\text { 4. 디지털 헬스 기반 적정 질병관리 기술 이전 및 지속적 교류 }\end{array}$ \\
\hline 환경 & $\begin{array}{l}\text { G6, G7, G13, } \\
\text { G14, G15 }\end{array}$ & $\begin{array}{l}\text { 친환경 적정기술 적용을 통한 } \\
\text { 인간과 공존하는 건강한 생태 } \\
\text { 계 구축 }\end{array}$ & $\begin{array}{l}\text { 핵심 전략 : 환경적정기술 현지사업화를 통한 신산업 생태계 구축 } \\
\text { 1. 메콩델타지역 고탁도, 고염분 원수 대응 수처리 기술 } \\
\text { 2. 도시지역 대기환경 개선을 위한 친환경 난방 기술 } \\
\text { 3. 지하수 오염물질 저감 기술 }\end{array}$ \\
\hline
\end{tabular}

표 및 과제를 요약한 것으로, 10 개 분야는 단일 또는 다수 의 SDGs와 연관되어 있는데, SDGs 중 G12(Responsible consumption and production, 지속가능소비생산 증진)와 G16(Peace, justice and strong institutions, 평화로운 정의 사 회 제도 구축)을 제외한 15 개의 SDGs를 반영하고 있다. 또 한, 각 과제는 3 개 내외의 중점 과제를 포함하여 총 30 개의
중점 추진 과제를 제시하였다.

\section{1 물 및 기후변화}

물 분야는 기존 물 관련 현지거점센터의 과제 지원 기간 이 종료되고, 소규모 단기 과제 위주로 진행되고 있는 ODA 사업의 제한사항을 보완하고자 국제협력을 통한 지속 가능 
한 물/위생 사업추진을 핵심 전략으로 선정하고 개인용 해 수담수기 개발 및 현지 실증, 저비용 막오염 측정 기술 개 발, 글로벌문제해결 현지거점 구축 등을 중점 과제로 제시 하였으며, 기후변화 대응 분야는 기존의 수원국 수준과 수 요를 간과하고 공급자 입장에서 단편적 수행하던 $\mathrm{ODA}$ 사 업의 문제점을 보완하고자 지속가능한 기후변화 대응력 확 보를 핵심 전략으로 선정하고 염분 침입 저지 및 섬/연안지 역 통합물관리, 지속가능성 확보를 위한 비즈니스 모델 개 발을 제안하였다.

\section{2 에너지 및 글로벌문제해결거점}

에너지 분야는 과거 단순한 에너지 기술 중심의 $\mathrm{ODA}$ 를 탈피하여 현지 운영을 통한 지속 가능성을 확보하고자 지 속 가능한 에너지 보급 및 지역 성장을 핵심 전략으로 하 여, K-ODA 에너지 리빙랩 테스트베드 및 확장성 기반 에 너지 유닛 개발, 스마트 통합전략관리 기술 개발과 함께 비 즈니스형 에너지 기술 개발을 통한 지속가능성 확보를 중 점과제로 선정하였다. 한편, 글로벌문제해결거점 분야는 기 존 8 개 거점센터의 주요 성과를 활용하여 2단계로 도약하 고 확장하기 위해 개발도상국에 대한 포용적 시장 확대와 지속 가능 개발을 핵심 전략으로 하고 2단계 전략 기술의 ICT 패키징 및 스마트시스템 구축과 리빙랩 중점기술에 대 한 스마트 연계체계 개발, 거점센터의 기술 성과에 대한 운 영지원을 통한 글로벌 통합기술 비즈니스 지원 플랫폼 추 진을 중점과제로 제시하였다.

\subsection{ICT 및 국제협력}

ICT 분야는 인프라 중심의 ODA 사업을 수원국 현지 주 민을 대상으로 하는 풀뿌리 밀착형 사업 플랫폼으로 전환 하기 위하여 ICT Villiage, ICT Education, ICT Start-up을 핵 심 전략으로 하여, 마을 ICT 센터 및 오픈소스 기반 ICT 교 육 컨텐츠 플랫폼 구축, 글로벌 스타트업 경진대회 개최를 중점과제로 선정하였다. 국제협력 분야는 국가 사업 중심의 $\mathrm{ODA}$ 추진으로 인한 글로벌 수준에서의 다양한 이해관계자 연계가 미약한 점과 과학기술 분야의 대표성을 가지는 단 일 창구가 부재하여 분산된 협력만 진행되고 있는 점을 보 완하고자, 글로벌 다자협력 디지털 플랫폼 구축과 함께 국 제사회의 포용적 과학기술 문화 형성을 핵심전략으로 제시 하며 과학기술 ODA 국제협력을 위한 다자협력 플랫폼 및 인력양성 기반 설계를 중점과제로 제시하였다.

\section{4 사회혁신 지속가능 및 교육}

과학기술 기반 사회혁신 및 지속가능 분야는 사회적 주
체들의 활동이 취약한 개발도상국에서 과학기술을 기반으 로 한 사회혁신을 유도하고자, 지속가능한 사회혁신 구현을 핵심 전략으로 하여 개도국 지역거점 소통협력공간 조성, 사 회혁신 선도사업 추진, 사회적 가치 내재화 및 확산을 통한 사회혁신 기반 구축을 중점과제로 선정하였다. 과학기술 교 육 분야에서는 수원국의 과학기술 분야 교원의 질적, 양적 부족에 대한 극복과 산업과 연계된 기술 교육의 확충을 위 하여 기술교육연계 산업 육성 및 온라인 교육시스템 구축 을 핵심 전략으로 하여 시니어 과학기술자를 활용한 공학 교육, 비대면 온라인 ICT-과학기술 교육, 청년 적정기술 개 발도상국 창업 교육 등의 교육 지원 사업과 함께 제 3 세계 현지 문제 해결형 적정기술 리빙랩 사업을 제안하였다.

\section{5 보건의료 및 환경}

최근 코로나 19 등으로 개발도상국을 포함한 글로벌 이슈 로 확대되고 있는 보건의료 분야는 수원국의 기존 비감염 성 만성질환과 함께 감염성 질환의 이중적 어려움에 대한 지원을 위해 디지털 기술기반 저비용 고효율 적정 질병관 리 기술 구축을 핵심 전략으로 제시하고 신종 감염병 대응 체계 구축, 비감염성 만성질환 적정 관리 기술 개발, 포스 트 코로나 시대의 의료 인력 양성 및 디지털 기반 질병관 리 기술 지원 등을 중점 추진과제로 제시하였다. 한편, 환 경 분야는 기존의 개별적 환경오염에 대한 관심이 기후변 화로 인해 수반되는 식수오염 및 물부족, 대기오염, 산림파 괴 등의 광범위한 문제로 전환되어야 함을 강조하고, 환경 적정기술 현지사업화를 통한 신산업 생태계 구축을 핵심 전 략으로 하여, 고탁도, 고염분 원수 대응 수처리 기술, 도시 지역 대기환경 개선을 위한 친환경 난방 기술, 지하수 오염 물질 저감 기술 등을 중점 과제로 제안하였다.

SDGs 실현을 위한 과학기술 ODA 로드맵은 지금까지 추 진된 각 분야에서의 과학기술 $\mathrm{ODA}$ 에 대한 현상을 분석하 고 SDGs 실현을 위한 향후 10 년간 수행하여야 할 핵심 전 략과제와 중점과제를 잘 제시해주고 있다. 하지만, 30 개의 중점 과제들 중 일부는 유사한 내용을 통합하여 추진하는 것이 효과적일 수 있고, 과제 진행 간 공통적으로 요구되는 여건과 상황이 있을 수 있다. 이러한 상황에서 각 분야별로 해당 과제들을 독립적으로 추진한다면 과제 관리의 복잡성 과 함께 향후 종합적인 성과측정이 제한될 수 있을 것이다. 또한, 연계 가능한 과제들을 공통으로 추진한다면 효과적인 성과의 도출 뿐만 아니라 시간과 노력의 소요도 감소시킬 수 있을 것이다. 이에, 각 분야별 중점과제를 분석하여 단 기 및 중기 추진과제를 도출하고, $\mathrm{SDGs}$ 를 효과적으로 실현 하기 위한 추진방안을 구체화 하고자 한다. 


\section{SDGs 실현을 위한 과학기술 ODA 로드맵 중 - 단기과제 도출}

\section{1. 중점과제 분석}

과학기술 $\mathrm{ODA}$ 로드맵의 효과적인 추진을 위한 중·단기 과제 도출을 위해, 로드맵의 중점과제에 대한 키워드를 분 석하였다. Figure 2는 과학기술 ODA 로드맵 중점과제 키워 드 분석 결과로서, 총 30 개 중점과제 중 각 분야별 고유 기 술개발 및 자체 추진과제 13 개를 제외한 나머지 17 개 과제 가 공통으로 포함하고 있는 4 개의 키워드를 확인할 수 있 었다.

총 17 개 과제 중 4 개 과제는 'ICT / 스마트화'를, 2 개 과 제 및 1 개 분야는 '글로벌문제해결거점'을 기반으로 하고 있 었으며, ‘협력 및 소통 플랫폼'에 3 개 과제가, '비즈니스 모 델 / 창업지원 플랫폼 / 리빙랩'에 가장 많은 8개 과제가 집 중되고 있었다. 이러한 공통의 지향점을 반영하여 각 분야 가 함께 추진할 수 있는 여건을 구축한다면, 로드맵 추진에 있어 탄력과 시너지 효과를 기대할 수 있을 것이다.

\section{2. 단기 및 중기 추진 과제 도출}

Table 2 는 중점과제 분석을 통해 도출한 키워드를 각 분 야의 중점과제 내용을 반영하여 단기 및 중기 추진과제로 재구성한 결과이다. 중.단기 과제는 17 개 중점과제의 추진
을 위해 선행적으로 수행되어야 할 여건 조성과 함께 실제 중점과제의 목표 달성을 위한 세부 추진 내용을 포함하고 있다.

단기과제로는 과학기술 ODA 네트워크 구축과 리빙랩 연 계 창업지원 비즈니스 플랫폼 구축을 제시하였다. 과학기술 $\mathrm{ODA}$ 네트워크 구축은 수원국과 국내, 또는 수원국 상호간 의 사업관리자 및 연구자들이 함께 소통하며 정보와 사례 를 공유할 수 있는 플랫폼을 구축하는 것으로, ICT기술을 기반으로 실시간 정보공유가 가능한 시스템을 구축하여 학 회, 포럼, 워크샵 등을 통해 과학기술 ODA 사업의 성과를 공유하고 확산할 수 있을 것이다. 리빙랩 연계 창업지원 비 즈니스 플랫폼 구축은 과학기술 ODA 사업의 성과를 수원 국 현지에서 자생적으로 지속가능하도록 시스템을 구축하 는 것으로, 현지에 리빙랩을 설립하고 이를 기반으로 비즈 니스 모델 개발 및 창업지원 등의 지속가능한 사업으로의 확장을 추진하고자 하는 것이다. 또한, 각 리빙랩의 중점기 술을 스마트화하여 과학기술 ODA 네트워크와 연계하여 공 유한다면, 보다 큰 효과를 기대할 수 있는 글로벌 리빙랩의 구축이 가능할 것이다.

중기과제는 수원국 현지 스마트화와 글로벌 문제해결거 점 확장 및 지속성 확보로 도출되었는데, 수원국 현지 스마 트화는 우리나라 과학기술의 강점 중 하나인 ICT 기술을 이 용하여 과학기술 $\mathrm{ODA}$ 사업을 스마트 시스템으로 구축하

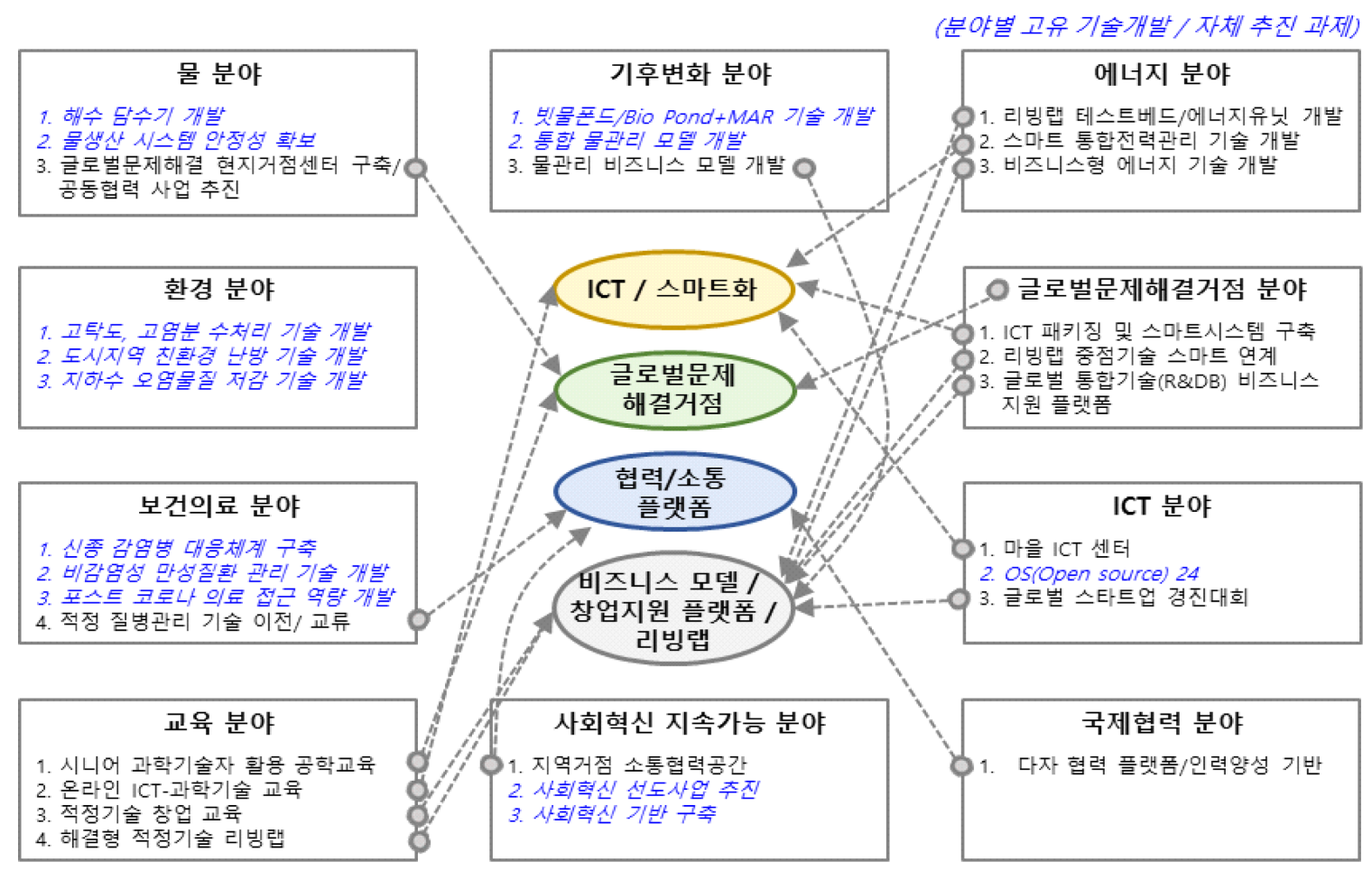

Figure 2. 과학기술 ODA 로드맵 중점과제 키워드 분석 
Table 2. 효과적 과학기술 ODA 로드맵 추진을 위한 중·단기과제 도출

\begin{tabular}{|c|c|c|c|}
\hline 구분 & 과제명 & 관련 중점과제 & 세부 추진내용 \\
\hline 단기 & $\begin{array}{l}\text { 1. 과학기술 ODA 네트워크 } \\
\text { 구축 }\end{array}$ & $\begin{array}{l}\text { 국제협력-1 } \\
\text { 사회혁신-1 } \\
\text { 보건의료-4 }\end{array}$ & $\begin{array}{l}\text { - 수원국 현지 및 국내를 연결하는 과학기술 ODA 소통 플랫폼 구축 } \\
\text { - 학회, 포럼, 워크샵 등 성과확산 프로그램을 통한 정보 및 우수사례 공유 }\end{array}$ \\
\hline 단기 & $\begin{array}{l}\text { 2. 리빙랩 연계 창업지원 비즈 } \\
\text { 니스 플랫폼 구축 }\end{array}$ & $\begin{array}{l}\text { 기후-3 } \\
\text { 에너지-1, } 3 \\
\text { 글로벌-2, } 3 \\
\text { ICT-3 } \\
\text { 교육-3, } 4\end{array}$ & $\begin{array}{l}\text { - 글로벌 리빙랩 구축을 통한 자생적 지속가능 시스템 구축 } \\
\text { - 국제 창업경진대회, 비즈니스 모델 경진대회 등을 통한 리빙랩 기반 프 } \\
\text { 로그램 개발 및 운영 } \\
\text { - 글로벌 리빙랩 중점기술 스마트 연계체계 구축 및 기술 공유 } \\
\text { * 과학기술 ODA 네트워크 구축과 연계 }\end{array}$ \\
\hline 중기 & 3. 수원국 현지 스마트화 & $\begin{array}{l}\text { 에너지-2 } \\
\text { 글로벌-1 } \\
\text { ICT-1 } \\
\text { 교육-2 }\end{array}$ & $\begin{array}{l}\text { - ICT 패키지 및 스마트 시스템 구축 : 과학기술 ODA 사업, 마을, 기반 } \\
\text { 산업 등 } \\
\text { - 수원국별 스마트 시스템의 글로벌 공유 플랫폼 구축 }\end{array}$ \\
\hline 중기 & $\begin{array}{l}\text { 4. 글로벌문제해결거점 확장 } \\
\text { 및 지속성 확보 }\end{array}$ & $\begin{array}{l}\text { 글로벌 전 과제 } \\
\text { 물-3 } \\
\text { 교육-1 }\end{array}$ & $\begin{array}{l}\text { - 과학기술 ODA 및 적정기술 국제협력 플랫폼으로서 글로벌문제해결거 } \\
\text { 점 확보 } \\
\text { - 전문 기술인력 양성 및 기술 현지화를 위한 테스트베드 구축 } \\
\text { - 현지 협력사업 발굴을 통한 지속가능성 확보 }\end{array}$ \\
\hline
\end{tabular}

고, 이를 마을과 리빙랩, 기반산업 등으로 확장하는 한편, 타 수원국의 스마트 시스템과 글로벌 공유를 추진하는 것이 다. 글로벌문제해결거점 확장 및 지속성 확보는 2020년 이 후 신규사업이 중단된 글로벌문제해결 거점사업을 재개함 과 동시에 기존 거점을 활용하여 과학기술 $\mathrm{ODA}$ 사업의 중 심점으로 활용하는 방안으로, 글로벌문제해결거점의 현지 지속가능성을 위한 협력사업 발굴까지를 포함한다.

상기의 4개 중·단기 과제는 과제 자체로서 과학기술 ODA 중점과제가 될 수도 있으며, 각 분야 중점과제의 효과적 추 진을 위한 기반으로서 역할을 수행할 수도 있을 것이다. 각 분야별 고유 연구개발과제의 추진과 병행하여 상기 중·단 기 과제를 우선적으로 추진한다면 과학기술 ODA 로드맵은 소기의 성과를 충분히 달성할 수 있을 것이다.

\section{글로벌문제해결거점 ICT화를 통한 과학기술 ODA 로드맵 중 - 단기 과제 추진 방안}

\section{1. 글로벌문제해결거점의 현재}

도출된 과학기술 $\mathrm{ODA}$ 로드맵의 효과적 추진을 위한 중 -단기 과제는 수원국 현지에서의 활동이 큰 비중을 차지한 다. 현지의 상황과 여건을 고려한 물리적인 활동이 요구되 는 부분이 많은데, 수원국 현지에서 이러한 역할을 수행하 는 기관을 과학기술 ODA 각 사업마다 구축하는 것은 쉽지 않을 것이다. 하지만, 동남아시아 및 아프리카에 과기정통 부의 지원 사업으로 설치된 글로벌과학기술거점을 기반 기 관으로 활용한다면 보다 효과적인 과학기술 ODA 사업 추 진이 가능할 것이다.
글로벌문제해결거점(구. 적정과학기술거점센터)은 2013 년 캄보디아 글로벌 물 거점센터를 시작으로 2020년까지 총 8개의 센터가 설립되어 운영되고 있다(Figure 3). Figure 4는 글로벌문제해결거점의 주요 사업내용 및 운영모델로서, 각 거점은 수원국 현지에 물, 농업, 위생, 에너지, 환경, IoT 등 다양한 과학기술 분야에 대한 센터를 개설하고 현지형 기 술 R\&D, 기술교육 역량강화, 사업화 및 창업지원 등의 활 동을 동시에 수행하며 과학기술 ODA에 큰 역할을 담당하 고 있다[최의소 등, 2015; 한윤식 등, 2017; 김지수 등, 2019; 맹민수 등, 2020. 하지만, 글로벌문제해결거점 사업이 일몰 사업화되어 중단된 상황으로, 기 구축된 각 거점의 훌륭한 인프라가 지속성을 잃을 상황에 놓여 있다. 이에 글로벌문 제해결거점의 2 단계 사업 추진전략에 대한 대안이 제시되 기도 하였다(맹민수 등, 2021).

\section{2. 글로벌문제해결거점의 ICT화}

임형백(2016)은 SDGs의 세부목표 달성을 위해서는 공여 국 및 수원국의 유관 기관들이 협력 네트워크를 구축하는 것에 대한 필요성을 강조하였는데, 이는 ODA 사업이 국가 적 차원에서 추진되는 사업이므로 현지에서 발생할 수 있 는 다양한 상황에 효과적으로 대응하기 위해서는 이해관계 자들이 수시 또는 정례적으로 정보 및 의견을 교환할 수 있 는 통로가 반드시 필요하기 때문이다. 과학기술 ODA 사업 의 경우에는 수원국 현지에서 사업을 진행하며 도출된 노 하우와 성과의 공유가 타 사업의 추진에 큰 도움이 될 수 있으며, 현지에서 발생하는 새로운 문제점에 대해 관련 과 학기술자들과 함께 논의할 수 있는 시스템이 구축된다면 이 


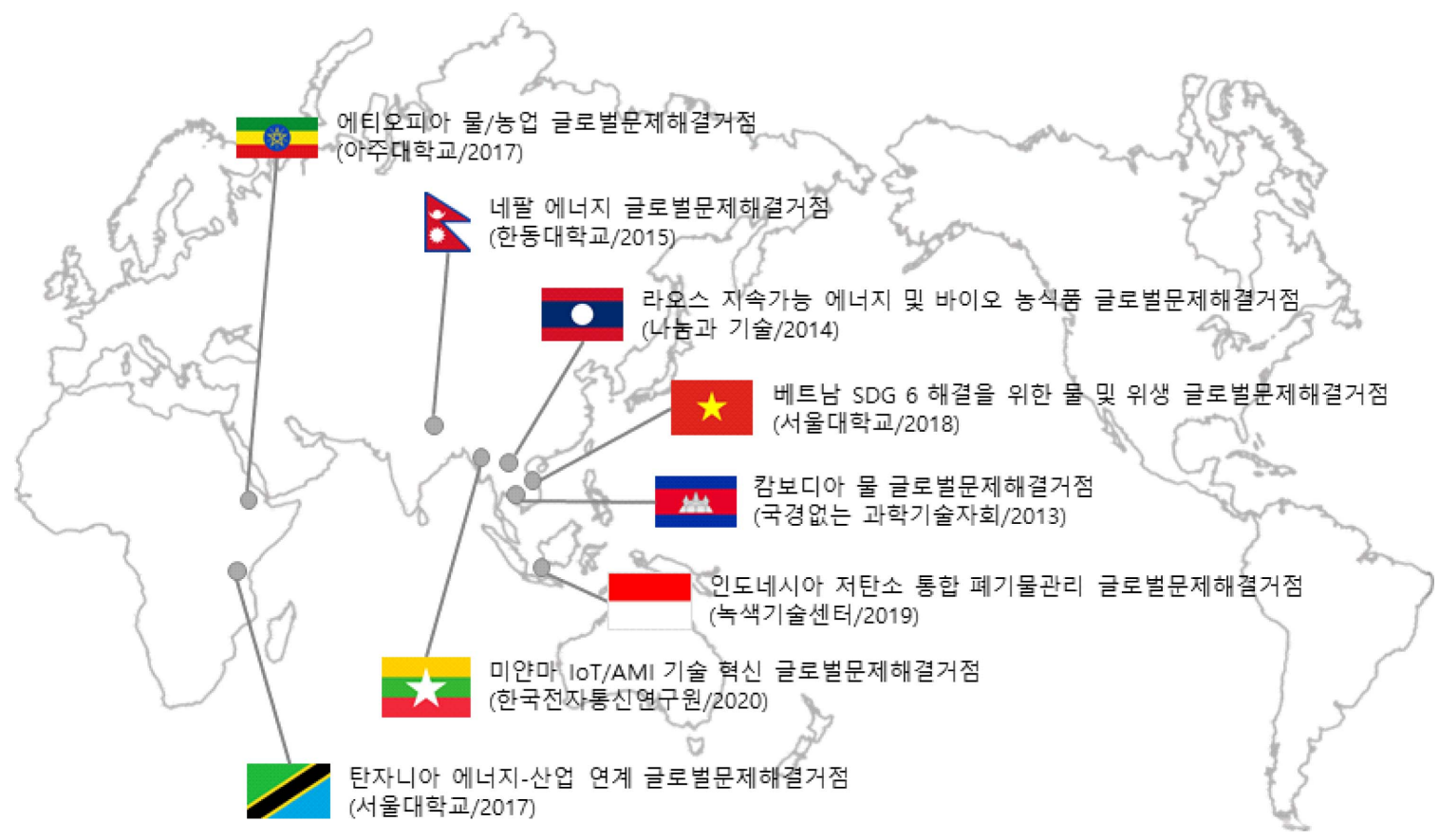

Figure 3. 글로벌문제해결거점 운영 현황

를 문제해결의 구심점으로 활용할 수 있을 것이다.

한편, 경제협력개발기구(OECD, Organization for Economic Cooperation And Development)의 개발원조위원회(DAC, Development Assitance Committee)에서는 과학기술 ODA와 $\mathrm{ICT} \mathrm{ODA}$ 를 별도로 정의하고 있지는 않으나, ICT ODA를 통신 및 라디오/텔레비전 등과 같이 협의의 범위로 지정하 고 있다(강희종 \& 임덕순, 2014). 우리나라는 세계 최고 수 준의 ICT 강국으로, 과학기술정보통신부는 이러한 강점을 이용하여 개도국에 대한 정보이용환경 개선사업, 정책 자문, $\mathrm{K}-\mathrm{Lab}$ 설치 및 운영 등 다양한 ICT ODA 사업을 추진하고 있다(국제개발협력그룹 등, 2020). 과학기술 $\mathrm{ODA}$ 사업 또 한 ICT 기술을 이용하여 스마트화가 가능한데, 수원국 현 지의 특성을 고려한 인터넷 통신을 적용하고, 개도국에서 예 산적인 부담없이 채택할 수 있는 적정기술을 적용하여 스 마트화를 추진하여 유관기관과 공유한다면 사업 성과의 제
고와 함께 다양한 분야로의 확장이 가능할 것이다.

상기의 과학기술 $\mathrm{ODA}$ 추진과 관련된 요구 사항은 글로 벌문제해결거점의 ICT화로 귀결될 수 있다. World Bank Group은 ICT가 변화와 혁신, 연결을 촉진할 수 있으며 ODA 를 보다 개방적이면서도 책임감 있게 할 수 있다고 제시하 였는데(World Bank Group, 2012), 수원국 현지에서 활동하 는 글로벌문제해결거점을 ICT화하여 과학기술 ODA의 전 초기지로 활용한다면 요구되는 다양한 활동들을 효과적으 로 수행할 수 있을 것이다.

전덕우는 SDGs 구현에 있어서 ICT의 적용으로 기대할 수 있는 혁신을 녹색기술센터가 인도네시아 글로벌문제해결거 점을 기반으로 추진하고 있는 기후 대응을 예시로 Figure 5 와 같이 제시하였다(Jun, 2021). 글로벌문제해결거점의 ICT 화는 ODA 사업에 있어서 재정적, 사회적, 기술적 혁신의 범 위를 확장시킴과 동시에 결과물에 대한 지속가능성이 충분

\begin{tabular}{|c|c|c|c|}
\hline $\begin{array}{c}\text { 현지형 기술 R\&D } \\
\text { (Technology) }\end{array}$ & \multicolumn{2}{|c|}{$\begin{array}{c}\text { 기술교육 역량강화 } \\
\text { (Education) }\end{array}$} & $\begin{array}{c}\text { 사업화 및 창업지원 } \\
\text { (Business) }\end{array}$ \\
\hline $\begin{array}{c}\text { 현지기반구축 } \\
\text { (6개월) }\end{array}$ & $\begin{array}{c}\text { 기술개발/현지화 } \\
\text { (1년 6개월) }\end{array}$ & & $\begin{array}{c}\text { 상용화/확산 } \\
\text { (6개월) }\end{array}$ \\
\hline $\begin{array}{l}\text { · 기술인력파견 } \\
\text { · 센터 설립 } \\
\text { · 현지특성연구 } \\
\text { · 기술인벤토리구축 }\end{array}$ & $\begin{array}{l}\text { · 대표기술개발 } \\
\text { · Pilot Plant 실험 } \\
\text { · 교육훈련활동 } \\
\text { · 시범사업준비 }\end{array}$ & 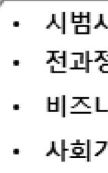 & $\begin{array}{l}\text { - 지역개발/수익사업 } \\
\text { - 프로그램보급확대 } \\
\text { - 국가우선정책화 } \\
\text { - 중장기로드맵개발 }\end{array}$ \\
\hline
\end{tabular}

Figure 4. 글로벌문제해결거점 사업내용 및 운영 모델[8] 


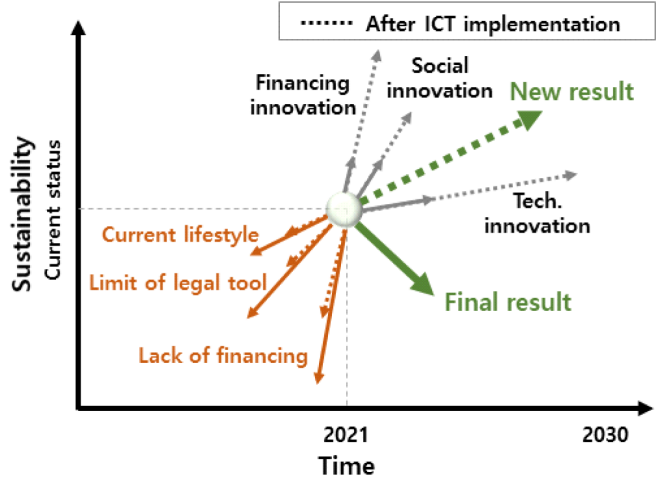

Figure 5. ICT를 통한 기후 대응 혁신(Jun, 2021)

히 보장될 수 있음을 보여준다고 할 수 있다.

\section{3. 글로벌문제해결거점 ICT화 추진 방안}

맹민수 등은 글로벌문제해결거점의 전략적 발전 방향에 대해 ICT 패키지 및 스마트 시스템의 구축을 제시하고 이 를 통해 거점센터의 2 단계 확장을 제안하였다(맹민수 등, 2021). 본 연구에서는 보다 구체적으로 글로벌문제해결거점 의 ICT화 추진 방안을 제시하고자 한다. 각 거점센터는 특 화된 중점사업을 추진하고 있는데, 각 거점센터가 ICT화되 기 위해서는 이러한 거점별 중점사업의 ICT화가 최우선되 어야 한다. 중점사업의 ICT화 이후에는 부수 기반사업의 $\mathrm{ICT}$ 화가 필요한데, 중점사업과 연계되어 시너지 효과를 창 출하거나, 중점사업의 지속가능성을 위해 추진되어야 하는 다양한 부수 및 기반사업 또한 ICT화가 병행되어야 한다.
최종적으로는 타 사업지역(거점)과 연결이 가능한 ICT 네 트워크 확장이 필요하다. 이 과정을 통해 글로벌문제해결거 점들이 하나로 연결되어 정보의 공유와 함께 공동의 문제 를 보다 효율적으로 해결할 수 있을 것이다.

Figure 6 은 탄자니아 글로벌문제해결거점의 ICT화 추진 사례를 보여주고 있다. 에너지-산업 연계 거점인 탄자니아 센터는 중점사업인 태양광 발전소 건설 및 지역 전력망 시 스템에 ICT 기반의 스마트미터를 설치하고 전체 시스템을 연결하여 실시간 모니터링을 추진하였다. 또한, 부수사업인 농업용수 관개시스템에도 ICT 기술을 접목하는 한편, 기반 사업인 Tech-shop에도 ICT를 적용하여 스마트화를 추진하 였다. 최종적으로 타 거점센터와 연결될 수 있는 플랫폼이 구축된다면 보다 완성도 높은 글로 벌문제해결거점의 ICT화 가 가능할 것이다. 앞서 도출된 과학기술 ODA 로드맵 추 진을 위한 중·단기과제인 과학기술 ODA 네트워크 구축, 리 빙랩 연계 창업지원 비즈니스 플랫폼 구축, 수원국 현지 스 마트화, 글로벌문제해결거점 확장 및 지속성 확보는 이러한 글로벌문제해결거점의 ICT화 과정을 통해서 효과적으로 구 현이 가능할 것이다.

\section{Conclusions}

본 논문에서는 $\mathrm{SDGs}$ 실현을 위한 과학기술 $\mathrm{ODA}$ 로드맵 을 분석하여 이를 효과적으로 추진하기 위해 선행적으로 수 행하여야 할 중·단기 과제를 도출하고 추진 방안을 제시하 였다. 단기과제로는 과학기술 ODA 네트워크 구축과 리빙

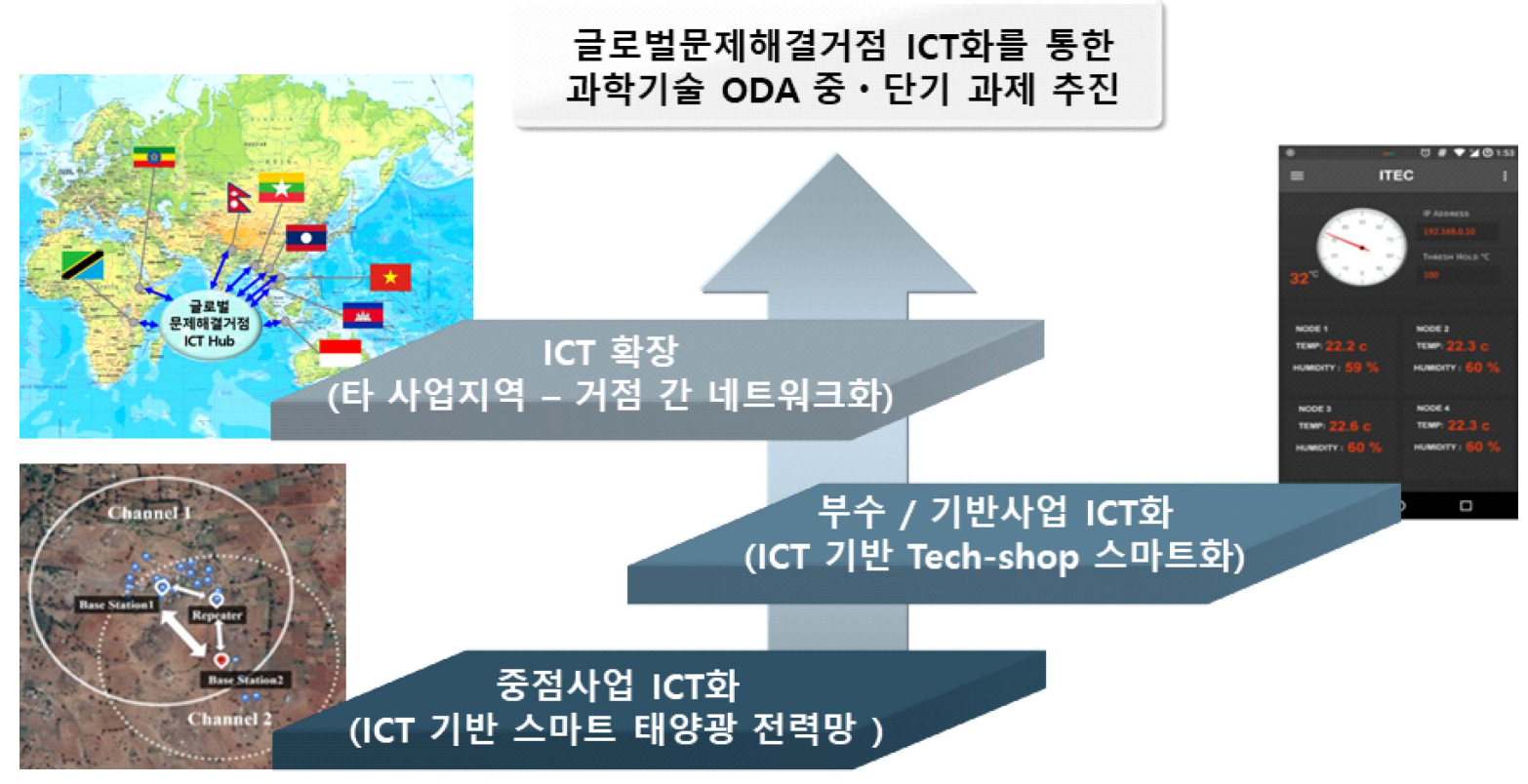

Figure 6. 탄자니아 에너지-산업 연계 글로벌문제해결거점 ICT화 추진 방안 
랩 연계 창업지원 비즈니스 플랫폼 구축을, 중기과제로 수 원국 현지의 스마트화와 글로벌문제해결거점 확장 및 지속 성 확보를 제안하였는데, 도출된 중·단기 과제는 글로벌문 제해결거점을 ICT화 하고 이를 중심으로 추진할 때 큰 효 과를 볼 수 있을 것으로 판단된다.

글로벌문제해결거점의 ICT화는 8 개 거점센터의 현지 활 동에 대한 데이터를 수집하고 저장 및 분석함으로써 중점 사업의 성과에 대한 가시화 및 스마트화를 가능하게 할 수 있을 것이다. 또한, ICT 인프라 및 역량을 수원국 사업지역 으로 확장함으로써 사업 성과의 확대가 가능할 것이다. 부 가하여, 글로벌문제해결거점간의 정보, 역량 및 자원을 공 유함으로써 국제협력 솔루션으로의 접근 또한 가능할 것이 다(Rhee, 2021).

2020년 6월에 발표된 SDGs 국가별 이행 상황에서, 우리 나라는 166 개국 중 20 위를 차지하였으나, G4. 교육부문을 제외하고는 대부분 주의 또는 위험 수준이며, 기후변화를 포 함하여 4개 목표에서는 심각 수준으로 평가되고 있다(정지 선 \& 유애라, 2020). SDGs의 달성은 단순한 의무에 대한 이 행이 아니라 우리의 생존을 위한 활동으로 인식되어야 할 것이다. 각계 전문가들의 깊은 고민을 통해 도출된 SDGs 실 현을 위한 과학기술 ODA 로드맵의 효과적인 추진을 통해 우리나라의 SDGs 이행이 보다 높은 성과를 올리는 한편, 공 여국과 수원국 모두가 상생하는 과학기술 ODA 사업이 진 행될 수 있기를 기대한다.

\section{Acknowledgements}

이 논문은 과학기술정보통신부의 재원으로 수행된 2021 년 정책연구과제 '글로벌문제해결 거점 기반 과학기술 ODA 스마트화 및 네트워크 구축(과제번호: 2021070F524$00)^{\prime}$ 의 연구 결과입니다.

\section{References}

강인수, 김태은, 유성훈, 김진주, 정유미, 조수미. (2016). SDGs 체제하에서 과학기술 ODA 역할 및 효과성 제고 방안 연구, KISDI 정책연구 최종보고서(2016.02), 정보통신정책연구원. 강희종, 임덕순. (2014). 과학기술·ICT ODA 현황 및 정책 방향, STEPI Insight, 145, pp. 1-38.

국제개발협력그룹, 글로벌협력팀, 해외진출지원팀, 글로벌협 력사업, 글로벌보안협력팀. (2020). 2019 과학기술정보통신 부 ICT ODA 사업 성과, 적정기술학회지, 6(1), pp. 2-20.
김지수, 정우균, 하보라, 문지현, 이협승, 안성훈. (2019). 스마트 -독립전력망을 사용한 소규모 태양광 발전소의 건설과 운영: 한국-탄자니아 적정기술 거점센터의 사례, 적정기술학회지, 5(2), pp. 62-69.

맹민수, 박승용, 이혜인, 신귀암. (2020). 에티오피아 글로벌문 제해결거점 사업을 통한 식수 및 농업 적정기술 보급, 적정 기술학회지, 6(2), pp. 80-87.

맹민수, 안성훈, 문지현, 독고석. (2021). 2030 글로벌문제해결 거점 2단계 사업 추진전략 로드맵, 적정기술학회지, 7(1), pp. 115-124. Doi.org/10.37675/jat.2021.7.1.115

신관우, 정성필, 박헌균, 박은선. (2020). 신남방정책 확산 및 2030 SDGs 실현을 위한 과학기술ODA 추진 로드맵 도출, 과학기술정보통신부 정책용역연구과제 최종보고서(2020. 10).

안성훈, 독고석, 추원식, 장수영, 이우성, 유영제, 윤제용. (2017). 적정기술의 역할과 비전, 적정기술학회지, 3(1), pp. 6-10.

이향희, 이명진. (2020). 유엔 지속가능발전목표 이행을 위한 과 학기술혁신 국제논의 동향과 정책제언 : 과학기술혁신 국제 협력정책을 중심으로, STEPI Insight, 251, pp. 2-33.

임형백. (2016). 지속가능개발 목표(SDGs)에 대응한 한국 공적 개발원조의 대응 방향, 입법과 정책, 8(2), pp. 31-58.

정지선, 유애라. (2020). 국제사회의 SDGs 이행성과와 코로나 이후 한국의 ODA 정책과제, KIEP World Economy Today, 20(21), pp. 1-25.

최의소, 독고석, 맹민수. (2015). 캄보디아 글로벌 물 적정기술 거점센터 $(\mathrm{iWc})$ 소개, 적정기술학회지, 1(1), pp. 16-23.

한윤식, 김영인, 김윤선, 신병길, 송인혁. (2017). 히말라야 고산 지역민을 위한 네팔 적정과학기술거점센터 활동, 적정기술 학회지, 3(2), pp. 96-102.

Jun, Dukwoo. (2021). Implications of ICT on Green Technology Cooperation, Proceedings of International Conference on Energy, Aquatech, and Sustainability 2021 (ICEAS 2021), Seoul National University Siheung Campus, Siheung, Korea, August 11-13, 2021.

Korea SDGs (https://ncsd.go.kr/ksdgs)

Rhee, Herb. (2021). Regional Issues and Solutions Approach Utilizing Smart ICT in Tanzania, Proceedings of International Conference on Energy, Aquatech, and Sustainability 2021 (ICEAS 2021), Seoul National University Siheung Campus, Siheung, Korea, August 11-13, 2021.

UN SDGs Goals (https://sdgs.un.org/goals)

World Bank Group. (2012). ICT for Greater Development Impact, World Bank Group Strategy for Information and Communication Technology 2012-2015. 